\title{
Burial and thermal history modelling of the Upper Carboniferous strata based on vitrinite reflectance data from Bzie-Dębina-60 borehole (Upper Silesian Coal Basin, southern Poland)
}

\author{
Dariusz Botor ${ }^{1} \llbracket$, Ondřej Bábek $^{2}$
}

${ }^{1}$ AGH University of Science \& Technology, Faculty of Geology, Geophysics and Environmental Protection, 30-059 Kraków al. Mickiewicza 30, Poland

${ }^{2}$ Palacký University of Olomouc, Department of Geology, 17 listopadu 12, 77146 Olomouc, Czech Republic

Key words:

Upper Silesian Coal Basin, maturity modelling, vitrinite reflectance, temperature

$\neg$ botor@agh.edu.pl

Editor:

Marek Slobodník

\begin{abstract}
Integrated modeling of the coal rank in the Upper Carboniferous sediments of the BzieDębina-60 borehole from SW of the Upper Silesian Coal Basin was performed based on a new vitrinite reflectance measurements from the Westphalian A. Microscopic investigations of Westphalian samples in the Bzie-Debina-60 well have shown that organic matter is dominated by vitrinite maceral group. The coal rank in the well shows an increase with depth. The mean vitrinite reflectance values in these samples range from 0.76 to $1.07 \%$. One-dimensional forward modelling of thermal maturity in the Bzie-Dębina-60 borehole section has been performed in order to explain the burial and thermal history. The maximum temperature $\left(c .145^{\circ} \mathrm{C}\right)$ causing the coalification occurred in the Latest Carboniferous (c. $300 \mathrm{Ma}$ ). These processes were likely related to significant late Variscan burial heating in this area as indicated by previous authors.
\end{abstract}

Doporučená citace článku: Botor, D., Bábek, O. (2019). Burial and thermal history modelling of the Upper Carboniferous strata based on vitrinite reflectance data from Bzie-Dębina-60 borehole (Upper Silesian Coal Basin, southern Poland). - Geologické výzkumy na Moravě a ve Slezsku, 26, 1-2, 73-79.

DOI: https://doi.org/10.5817/ GVMS2019-1-2-73

\section{Introduction}

The processes of coalification in coal-bearing basins are mainly determined by the thermal evolution of a basin, which is directly related to its geological history. Therefore, the thermal maturity pattern of the organic matter (degree of coalification, coal rank) is directly proportional to the burial history of the analyzed lithostratigraphic profile and the heat transport through the rocks (Hantschel, Kauerauf 2009). The Upper Silesian Coal Basin (USCB) is one of the largest coal basins in Europe (Kotas 1995). However, the thermal evolution of the USCB is still a matter of controversy and a number of issues have not yet been clarified. Generally, reconstructions of the thermal history of this basin are traditionally based on geological evidences including organic matter maturity, mineral indices such as illite crystallinity and conodont alteration indices (CAI), but more recently also on K-Ar dating, apatite fission track and helium dating (e.g. Belka 1993; Kotas 1995, 2001; Środoń et al. 2006; Botor 2014; Geršlová et al. 2016). At least two groups of models for the thermal history of the USCB have been proposed. The first has maximum temperatures at the end of the Carboniferous, just prior to or slightly after the tectonic inversions that were related mainly to burial. In the second group scenario, maximum temperatures were related to a regional thermal pulse(s) either (i) in the Mesozoic, in response to unrecognized deep magmatism and/or fluid circulation related to regional tectonic activity, or (ii) additional burial, in the Miocene or Mesozoic (Belka 1993; Kotas 1995, 2001; Środoń et al. 2006; Botor 2014; Geršlová et al. 2016). The aim of 
this study was to determine the paleothermal conditions of coalification of the Upper Carboniferous coal-bearing strata in the SW part of the USCB on the example of the lithostratigraphic section of the Bzie-Dębina- 60 borehole, which was drilled in 2011.

\section{Geological setting}

The Upper Silesian Coal Basin is located in southern Poland and in the Ostrava region in NE part of the Czech Republic (Fig. 1). The USCB occupies the NE corner of the Brunovistulicum Block, the Neoproterozoic crystalline basement of which was consolidated during the Cadomian orogenic cycle (Kalvoda et al. 2008). The northern part of Brunovistulicum is defined as the Upper Silesian Block (Kotas 1985; Buła, Żaba 2005). The western part of Brunovistulicum extends beneath the MoravianSilesian Fold-and-Thrust Belt that evolved in response to Carboniferous subduction of the Brunovistulian terrane below the Lugodanubian group of terranes (e.g. Fritz, Neubauer 1995; Buła, Żaba 2005). From late Viséan to the Stephanian, the region acted as a peripheral foreland basin of the Moravo-Silesian part of the Variscan mobile belt, in which over c. $8000 \mathrm{~m}$ of Carboniferous molasse sediments were deposited, but have been reduced by erosion mostly after late Westphalian-Stephanian tectonic uplift (Kotas 1985, 1995; Kędzior et al. 2007). The molasse basin displayed asymmetric subsidence with an axis that followed continuously the eastward migration trend. The preserved coal-bearing sequence is 1500-2 $000 \mathrm{~m}$ thick in the eastern part of the basin and increases westward to over $4500 \mathrm{~m}$ (Fig. 2). Up to $1500 \mathrm{~m}$ of Upper Viséan to Lower Namurian flysch sediments marked the termination of fully marine deposition in the Moravo-Silesian Basin (Hradec-Kyjovice Formation). During the Early Namurian to Westphalian (Serpukhovian to Kasimovian) times, the basin was filled by paralic and subsequently limnic, fluvial, fluvio-lacustrine and lacustrine siliciclastics with frequent coal seams and volcanoclastic strata, which is subdivided into the Ostrava and Karviná Formations in the Czech Republic. In the Polish part, the USCB is subdivided into the Paralic Series (equivalent to Ostrava Fm.), the Upper Silesia Sandstone Series and Mudstone / Siltstone Series (equivalent to Karviná Fm.) and the Kraków Sandstone Series (see Jirásek et al. 2013 for more details).

The Namurian to Westphalian coal-bearing sediments are overlain by Stephanian Kwaczała Arkose and by up to $100 \mathrm{~m}$ of Lower Permian rocks, which are restricted to the narrow zone along NE margin of the USCB. Whereas, in the northern and the eastern part of the USCB the Carboniferous rocks are discordantly overlain by Triassic deposits, which range in thickness from 100 to $200 \mathrm{~m}$ and the southern part of USCB is covered up to $400 \mathrm{~m}$ by Miocene sediments (Kotas 1995).

The Moravian-Silesian Belt overrides the western margin of the USCB along a system of thrusts. The USCB forms a broad synclinorium, which is differentiated in deformation style. Along both main overthrusts there is a narrow zone of E-facing folds, which delimits the Variscan front of the
Fig. 1: A - Simplified sketch map showing the geotectonic position of the Upper Silesian Coal Basin, TTZ Teisseyre-Tornquist Zone; B - study area of the Upper Silesian Coal Basin (USCB) modified after Kotas (1995), Buła et al. (1997) and Kalvoda et al. (2008). 
Moravo-Silesian mobile belt. To the east, the basin has been primarily affected by brittle deformation. The main Variscan tectonic movements that resulted in the inversion of the basin occurred during Latest Westphalian to Stephanian time (Kotas 1985, 1995; Buła et al. 1997). More comprehensive discussion of USCB geology can be found in Kotas (1995), Buła et al. (1997) and Kędzior et al. (2007).

\section{Methods}

The Bzie-Dębina-60 borehole (maximum depth of $1341 \mathrm{~m}$ ) penetrated the succession of the Mudstone Series (Westphalian), overlain by Miocene deposits of the Carpathian Foredeep (Figs. 1, 2). The rock samples were cut perpendicular to the bedding and from these rock pieces polished slides were prepared for microscopic investigations. Vitrinite reflectance was measured to determine the coal rank of the samples, using a Zeiss AxioImager $2 \mathrm{mM}$ microscope for incident light, a $50 \times / 0.85$ Epiplan-Neofluar oil immersion objective and a $546 \mathrm{~nm}$ filter, Zeiss immersion oil $\mathrm{n}_{\mathrm{e}}=1.518$, at a temperature of $23^{\circ} \mathrm{C}$. Mineral standards of known reflectance were used for calibration: sapphire $(0.590 \%)$, yttrium-aluminum garnet $(0.901 \%)$, gadolinium-gallium garnet $(1.718 \%)$. The applied microscopical investigations closely followed the guidelines published by e.g. the usual International Committee for Coal and Organic Petrology (ICCP) procedures (ISO 7404-5, 2009), and further discussed by Pusz et al. (2014) and Hackley et al. (2015).

Computer modeling of the degree of coalification was carried out using the 1-D PetroMod software (Schlumberger). The modelling employed data defining the burial history, comprising the stratigraphy and thickness of the distinguished intervals as well as petrophysical parameters of rocks, the contemporary thermal regime and the present thermal maturity (Hantschel, Kauerauf 2009). The maturity was modelled using the forward method, i.e. first the initial state of the system and definite geological process were assumed, and then its effect on the contemporary distribution of thermal maturity in the profile was calculated. In the case of a discordance between calculated and measured maturity values, the procedure was repeated for other parameters until an optimum calibration was obtained (Hantschel, Kauerauf 2009). The backstripping method including corrections for decompaction of sediments was used to reconstruct the burial history. Petrophysical parameters were used based on default PetroMod library according to lithology types identified in the Bzie-Dębina-60 well. Models were calibrated using presentday corrected borehole temperature data (Karwasiecka 1996, 2001) and measured values of $R_{0}$. The basic parameter used to build the model of coalification was the average vitrinite reflectance using the algorithm according to Sweeney and Burnham (1990). A broader
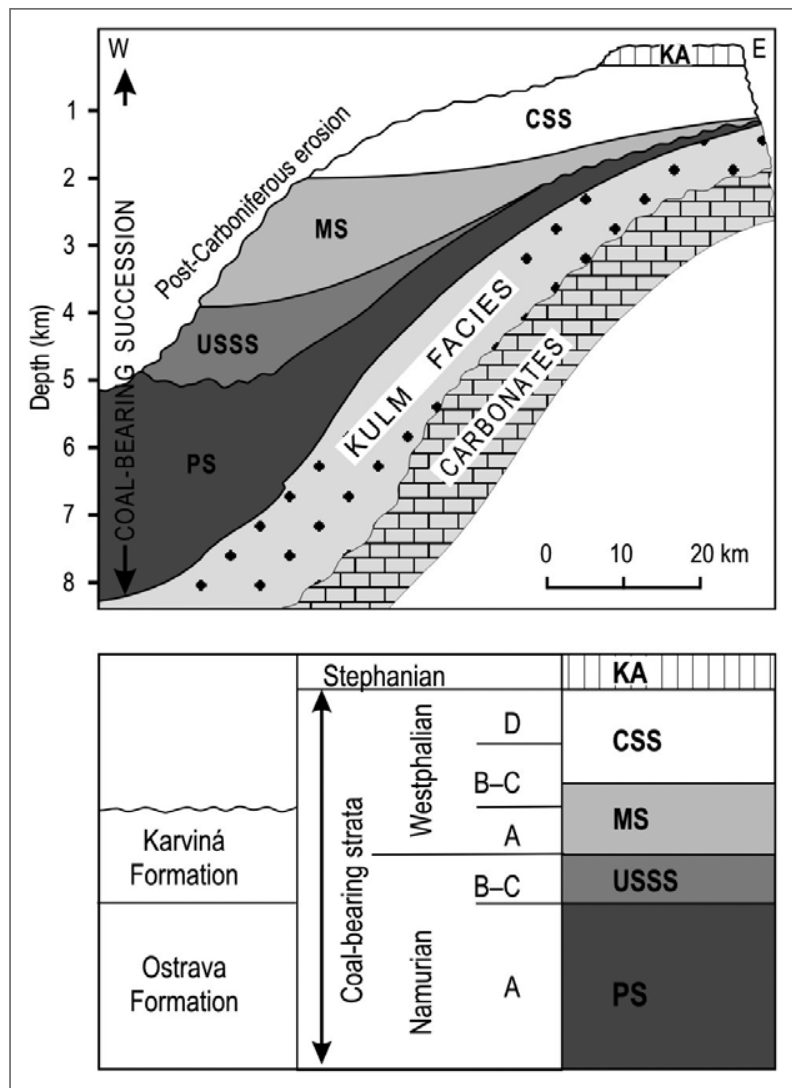

Fig. 2: Schematic lithostratigraphic cross-section through the Upper Silesian Coal Basin (after Kotas 1995). Clastic Culm facies and carbonates are Lower Carboniferous sediments. Coal-bearing strata include Namurian and Westphalian sediments only. KA - Kwaczala Arkose; CSS - Cracow Sandstone Series; MS - Mudstone Series; USSS - Upper Silesian Sandstone Series; PS - Paralic Series.

Tab. 1: Results of microscopic investigations of the samples (Załęże Beds, Westphalian A) from Bzie-Dębina-60 well.

\begin{tabular}{|r|l|c|c|c|c|c|c|c|c|}
\hline No & Sample & $\begin{array}{c}\text { Depth } \\
(\mathrm{m})\end{array}$ & Lithology & $\begin{array}{c}\mathbf{R}_{\mathbf{0}} \\
(\%)\end{array}$ & $\mathbf{N}$ & STD & $\begin{array}{c}\text { W } \\
(\%)\end{array}$ & L & I \\
\hline 1 & BD60/1 & 811.0 & claystone & 0.76 & 40 & 0.10 & 85 & 5 & 10 \\
\hline 2 & BD60/4 & 886.5 & coal & 0.80 & 100 & 0.04 & 89 & 3 & 8 \\
\hline 3 & BD60/7 & 910.9 & coal & 0.83 & 100 & 0.04 & 71 & 6 & 23 \\
\hline 4 & BD60/8 & 935.0 & claystone & 0.85 & 52 & 0.12 & 78 & 4 & 18 \\
\hline 5 & BD60/9 & 960.5 & claystone & 0.81 & 62 & 0.08 & 76 & 5 & 19 \\
\hline 6 & BD60/12 & 1032.9 & claystone & 0.83 & 56 & 0.08 & 80 & 3 & 17 \\
\hline 7 & BD60/14 & 1096.0 & claystone & 0.84 & 67 & 0.08 & 82 & 6 & 12 \\
\hline 8 & BD60/17 & 1140.0 & claystone & 0.84 & 48 & 0.08 & 79 & 5 & 16 \\
\hline 9 & BD60/18 & 1152.3 & coal & 0.87 & 100 & 0.05 & 77 & 4 & 19 \\
\hline 10 & BD60/22 & 1226.0 & claystone & 0.94 & 75 & 0.13 & 86 & 3 & 11 \\
\hline 11 & BD60/24 & 1285.0 & claystone & 1.02 & 64 & 0.14 & 85 & 5 & 10 \\
\hline 12 & BD60/26A & 1329.0 & coal & 1.07 & 100 & 0.05 & 79 & 4 & 17 \\
\hline 13 & BD60/26B & 1329.0 & claystone & 1.01 & 71 & 0.08 & 78 & 6 & 16 \\
\hline
\end{tabular}

Stratigraphically all samples are Westphalian A

(Załęże Beds, per. comm. Prof. Ireneusz Lipiarski)

$\mathrm{R}_{\mathrm{o}}$ - mean vitrinite reflectance (\%); $\mathrm{N}$ - number of measurements per sample; STD standard deviation; W - vitrinite group; L - liptinite group; I - inertinite group

discussion of the applied maturity modeling method is provided by Botor et al. (2013). 


\section{Results and discussion}

Microscopic investigations of Westphalian samples in the Bzie-Dębina-60 well have shown that organic matter is dominated by vitrinite group (Tab. 1). The coal rank in the well shows an increase with depth. The mean vitrinite reflectance values range from 0.76 to $1.07 \%$ (Tab. 1), which is similar to the data from the adjacent Bzie-Dębina-57 well (Probierz, Kwaśny 2014). In the Czech part of the USCB (SV4, NP824, NP522 wells, Bábek, Franců 2004), the vitrinite reflectance values range from 2.0 to $0.5 \%$ (Sivek et al. 2003; Bábek, Franců 2004; Kandarachevová et al. 2009). Further to west in the Moravo-Silesian Basin, the vitrinite reflectance values quickly increase to $>5 \%$ (e.g. Dvořák 1989; Franců et al. 1999; Bábek et al. 2005, 2006).

This new set of data was used for maturity modelling using the PetroMod software (Fig. 3, 4). The results show a quick increase in burial depths during the late Carboniferous time, immediately after the deposition of the Mudstone Series (which were drilled in the well, i.e. Westphalian A), leading to maximum burial depths in the end of the Carboniferous (Fig. 3). Subsequent burial phases in the Triassic and Miocene did not have any effect on the growth of paleotemperatures and the coalification of the Carboniferous sediments. The calculated values of the average vitrinite reflectance indicate a maximum palaeotemperature of c. $145^{\circ} \mathrm{C}$ (Fig. 3). Later burial temperatures were too low and insufficient to significantly increase the coalification of the organic matter (cf. Botor 2014). In the Bzie-Dębina-60 well, the present-day average heat flow, based on borehole temperature values (Fig. 4A), is $70 \mathrm{~mW} / \mathrm{m}^{2}$, which is similar to the published values from the area (Karwasiecka 1996, 2001). Within the USCB the average present-day heat flow is $70.4 \pm 8.5 \mathrm{~mW} \mathrm{\textrm {m } ^ { 2 }}$ (Karwasiecka 1996, 2001), which is in agreement with independent observations from the Ostrava-Karvina area corresponding to $70 \pm 8$

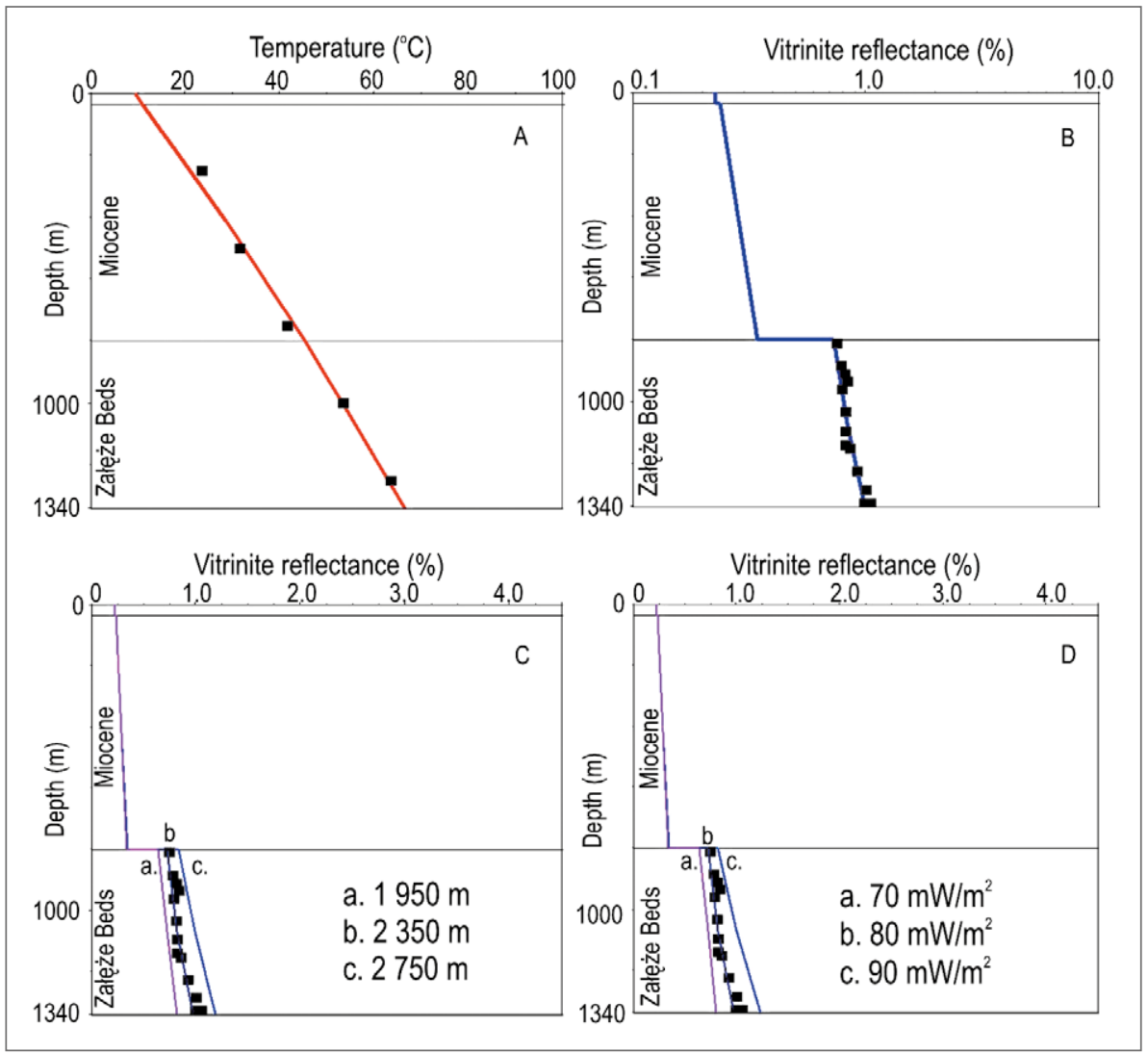

Fig. 4: Model calibration by present-day borehole temperature (A), by mean vitrinite reflectance values (B), sensitivity analysis applying change of overburden thickness (C), and change heat flow values in the time of maximum burial (D).
$\mathrm{mW} / \mathrm{m}^{2}$ (Kubik, Čermak 1986). In the SW part of the USCB in Poland, the heat flow values range from c. 70 to $\mathrm{c}$. $80 \mathrm{~mW} / \mathrm{m}^{2}$ (Karwasiecka 1996, 2001). However, coalification in inverted sedimentary basins is mainly controlled by conditions during deep burial, not by parameters of the present-day period (e.g. Hantschel, Kauerauf 2009), especially in the USCB where the degree of coalification at given depths is higher than it should be taking into account the present-day geothermal gradient. In this work, a correct (the best fitted, preferred) thermal model was obtained in accordance with the measured $\mathrm{R}_{\mathrm{o}}$ values for this borehole, assuming $2350 \mathrm{~m}$ of post-Variscan erosion of the Carboniferous overburden, and heat flow of 
$80 \mathrm{~mW} / \mathrm{m}^{2}$ at the end of Carboniferous (Fig. 4B). Sensitivity analyses of the models have shown that a change in erosions of $\pm 400 \mathrm{~m}$ or a change in heat flow of $\pm 10 \mathrm{~mW} / \mathrm{m}^{2}$ result in a significant change in calibration (Fig. $4 \mathrm{C}-\mathrm{D}$ ). Similar thickness of eroded strata was also recently calculated from the Czech part of the USCB (Geršlová et al. 2016).

Moreover, the preferred model is compatible with time-temperature history based on apatite fission track data (Botor 2014). In neighboring wells located in the western part of USCB, the Permian to early Triassic (259 to $214 \mathrm{Ma}$ ) apatite fission track ages clearly document that the maximum temperatures in the basin were reached much earlier, i.e. at the end of the Carboniferous. Considering the geological evolution of this area, its origin should be connected with the processes of burial directly before the tectonic inversion in the latest Carboniferous (Botor 2014). In the Moravo-Silesian Basin located to the $\mathrm{W}$, burial paleotemperatures inferred from vitrinite reflectance, illite crystallinity and conodont alteration indices reached 150 to $350{ }^{\circ} \mathrm{C}$ (late diagenetic to anchimetamorphic conditions), showing a distinct regional trend of decreasing thermal alteration from NW (interior of the orogene) to SE (foreland). The maximum burial temperatures may have coincided with a distinct thermal pulse at the NE margin of the Bohemian Massif as indicated by the intrusion of the Žulová Massif and 300-310 Ma cooling ages of white micas in the Silesicum domain (Maluski et al. 1995; Schulmann et al. 2014). However, the influence of the Žulová Massif intrusion on the thermal evolution of the USCB was probably low because of a significant distance between these two geological units (Fig. 1). In addition, porosity and bulk density data from the Carboniferous sediments (in particular, low porosity at relatively shallow depths, Botor et al. 2019) provide an indirect evidence for a significant erosion of overlying strata, i.e., much greater ancient burial depth of the sediments particularly in the western part of the USCB.

\section{Conclusions}

The diagenesis of Upper Carboniferous sediments in the Bzie Dębina-60 well is not related to the modern geothermal field, but is much older. The coalification occurred in the latest Carboniferous c. $300 \mathrm{Ma}$, and was likely related to significant burial and mildly higher heat flow compared to present-day. Any hydrothermal processes or tectonic extension associated with the suggested Mid-Mesozoic thermal event did not affect their coalification, presumably due to the lack of a significant increase in temperature above the values already achieved with the end of the Carboniferous.

\section{Acknowledgements}

The above work was supported by National Agency Academic Exchange (NAWA, Warsaw, Poland) as part of a scientific fellowship for Dariusz Botor, project No. PPN/ BIL/2018/1/11/CZE/UMOWA/1 at Palacký University of Olomouc, Department of Geology (Czech Republic) in the academic year 2018-2019. We would like to express our gratitude to the reviewers, Dr. Václav Suchý and the Anonymous Reviewer, for their very valuable input, which significantly improved the quality of the paper. 
References

Bábek, O., Franců, E. (2004). Regional trends in Thermal Maturity of Paleozoic Rocks of the Moravo-Silesian Basin: a Combined Study of Conodont Alteration Index (CAI), Vitrinite Reflectance and Rock Eval Pyrolysis. - Proceedings of the 2nd Meeting of the Central European Teconic Group, Lučenec, Slovakia, June 22-25, 2004, Geolines, 17, 16-17. Praha.

Bábek, O., Tomek, Č., Neubauer, F., Franců, E., Kalvoda, J. (2005). Thermal overprint in Paleozoic sediments of the Moravo-Silesian zone, Bohemian Massif: a record of late Variscan orogen-parallel extension. - Proceedings of the 3rd Meeting of the Central European Teconic Studies Group, Felsötarkányi, Hungary, April 14-17, 2005, Geolines, 19, 17. Praha.

Bábek, O., Tomek, Č., Melichar, R., Kalvoda, J., Otava, J. (2006). Structure of unmetamorphosed Variscan tectonic units of the southern Moravo-Silesian Massif: a review. - Neues Jahrbuch für Geologie und Paläontologie, Abhandlungen, 239, 37-75.

Belka, Z. (1993). Thermal and burial history of the Cracow-Silesia region (southern Poland) assessed by conodont CAI analysis. - Tectonophysics 227, 161-190. https://doi.org/10.1016/0040-1951(93)90093-Y

Botor, D., Papiernik, B., Maćkowski, T., Reicher, B., Kosakowski, P., Machowski, G., Górecki, W. (2013). Gas generation in the Carboniferous source rocks of the Variscan and their foreland. implications for a charge history of natural gases of the Rotliegend deposits (Poland). - Annales Societatis Geologorum Poloniae, 83, 353-383.

Botor, D. (2014). Timing of coalification of the Upper Carboniferous sediments in the Upper Silesia Coal Basin on the basis of by apatite fission track and helium dating. - Gospodarka Surowcami Mineralnymi - Mineral Resources Management, 30, 85-104 [In Polish, with English summary]. https://doi.org/10.2478/gospo-2014-0010

Botor, D., Karwasiecka, M., Wagner, J., Kwarciński, J., Krieger, W., Rolka, M. (2019). Attempt to estimate of Carboniferous eroded overburden in the Upper Silesian Coal Basin (Poland) based on integrated sediment compaction and thermal maturity data - preliminary results. SGEM Conference, 25.06-1.07.2019, Albena, Bulgaria, (submitted).

Buła, Z., Jachowicz, M., Żaba, J. (1997). Principal characteristics of the Upper Silesia Block and Małopolska Block border zone (southern Poland). - Geological Magazine, 134, 669-677. https://doi.org/10.1017/S0016756897007462

Buła, Z., Żaba, J. (2005). Geological position of the USCB versus Precambrian and Lower Paleozoic basement. - Przewodnik 76 Zjazdu Polskiego Towarzystwa Geologicznego, pp. 14-42. [in Polish with English abstract].

Dvořák, J., (1989). Anchimetamorphism in the Variscan tectogene in Central Europe - its relationship to tectogenesis. - Věstník Ústředního Ústavu Geologického, 64, 17-30. [In Czech, with English abstract].

Franců, E., Franců, J., Kalvoda, J. (1999). Illite crystallinity and vitrinite reflectance in Paleozoic siliciclastics in the SE Bohemian Massif as evidence of thermal history. - Geologica Carpathica, 50, 365-372.

Fritz, H., Neubauer, F. (1995). Moravo-Silesian Zone: Autochthon - Structure. - In: Dallmeyer, R.D., Franke, W., Weber K. (eds): Pre-Permian geology of Central and Eastern Europe, pp. 490-494, Springer, Berlin.

Geršlová, E., Goldbach, M., Geršl, M., Skupien, P. (2016). Heat flow evolution, subsidence and erosion in Upper Silesian Coal Basin, Czech Republic. - International Journal of Coal Geology, 154-155, 30-42.

Hantschel, T., Kauerauf, A. (2009). Fundamentals of Basin and Petroleum Systems Modeling. - Springer, Heidelberg.

Hackley, P. C., Araujo, C. V., Borrego, A. G., Bouzinos, A., Cardott, B. J., Cook, A. C., Eble, C., Flores, D., Gentzis, T., Gonçalves, P. A., Mendonça Filho, J. G., Hámor-Vidó, M., Jelonek, I., Kommeren, K., Knowles, W., Kus, J., Mastalerz, M., Menezes T. R., Newman, J., Oikonomopoulos, J. K., Pawlewicz, M., Pickel, W., Potter, J., Ranasinghe, P., Read, H., Reyes, J., De La Rosa Rodriguez, G., de Souza, I.V.A.F., Suárez-Ruiz, I., Sýkorová, I., Valentine, B.J. (2015). Standardization of reflectance measurements in dispersed organic matter: Results of an exercise to improve interlaboratory agreement. - Marine and Petroleum Geology, 59, 22-34.

International Organization for Standardization (ISO) (2009). Methods for the petrographic analysis of bituminous coal and anthracite - part 5: methods determining microscopically the reflectance of vitrinite. ISO $7404-5$, $3^{\text {th }}$ edition.

Jirásek, J., Hýlová, L., Sivek, M., Jureczka, J., Martínek, K., Sýkorová, I., Schmitz, M. (2013). The Main Ostrava Whetstone: composition, sedimentary processes, palaeogeography and geochronology of a major Mississippian volcaniclastic unit of the Upper Silesian Basin (Poland and Czech Republic). - International Journal of Earth Sciences, 102, 989-1006. https://doi. org/10.1007/s00531-012-0853-5

Kalvoda, J., Bábek, O., Fatka, O., Leichmann, J., Melichar, R., Nehyba, S., Špaček, P. (2008). Brunovistulian terrane (Bohemian Massif, Central Europe) from late Proterozoic to late Paleozoic: a review. - International Journal of Earth Sciences, 97, 497-518. https://doi.org/10.1007/s00531-007-0183-1

Kandarachevová, J., Sedláčková, L., Hýlová, L., Jirásek, J., Sivek, M. (2009). Lateral development of coalification in the Czech part of the Upper Silesian Coal Basin and its connection with gas deposits. - International Journal of Coal Geology, 79 (1-2), 29-39.

Karwasiecka, M. (1996). Geothermal Atlas of the Upper Silesia Coal Basin. Publishing House Państwowy Instytut Geologiczny, Warszawa. [in Polish].

Karwasiecka, M. (2001). Nowe wyniki badań gęstości powierzchniowego strumienia cieplnego Ziemi w obszarze Górnośląskiego Zagłębia Węglowego. - In: Plewa, S. (ed.): Rozpoznanie pola cieplnego Ziemi w obszarze Górnośląskiego Zagłębia Węglowego dla potrzeb górnictwa i ciepłownictwa, Studia, Rozprawy, Monografie, Instytut Gospodarki Surowcami Mineralnymi i Energią PAN, Kraków, 90, 50-84. [in Polish].

Kędzior, A., Gradziński, R., Doktor, M., Gmur, D. (2007). Sedimentary history of a Mississipian to Pennsylvanian coal-bearing succession: an examples from the Upper Silesia Coal Basin, Poland. - Geological Magazine, 144, 487-496. https://doi. org/10.1017/S001675680700341X

Kotas, A. (1995). Lithostratigraphy and sedimentological-paleogeographic development of the Upper Silesian Coal Basin. - In: Zdanowski, A., Żakowa, H. (eds): The Carboniferous System in Poland. Prace Państwowego Instytutu Geologicznego Warszawa, pp. 124-134. 
Kotas, A. (2001). Interpretation of thermal maturity gradients in the Carboniferous strata of the Upper Silesia Coal Basin. Proceedings of the XXIV Conference - Geology of coal-bearing formation of Poland, 2001, pp. 45-51, AGH Publishing House. [in Polish].

Kotas, A. (1985). Structural evolution of the Upper Silesian Coal Basin (Poland). - Comptes Rendus Geosciences, 3, 459-469. 10 th $^{\text {th }}$ Congr. Int. Strat. Coal Carb., Madrid 1983.

Kubík, J., Čermák, V. (1986). Heat flow in the Upper-Silesian Coal Basin: re-evaluation of data with special attention to the lithology. - Studia Geophysica et Geodaetica, 30, 376-393. https://doi.org/10.1007/BF01646381

Maluski, H., Rajlich, P., Souček, J. (1995). Pre-Variscan, Variscan and early Alpine thermo-tectonic history of the northeastern Bohemian Massif: a 40Ar/39Ar study. - Geologische Rundschau, 84, 345-358. https://doi.org/10.1007/s005310050010

Probierz, P., Kwaśny, M. (2014). Changes of coal rank and petrographic composition of coals from the drillhole BD 57 deposit of "Bzie-Dębina" in the Jastrzębie area (SW part of the Upper Silesian Coal Basin). - Geology, Geophysics and Environments, 40, 66-74. https://doi.org/10.7494/geol.2014.40.1.66

Pusz, S., Borrego, A. G., Alvarez, D., Camean, I., du Cann, V., Duber, S., Kalkreuth, W., Komorek, J., Kus, J., Kwiecińska, B. K., Libera, M., Marques, M., Misz-Kennan, M., Morga, R., Rodrigues, S., Smędowski, Ł., Suarez-Ruiz, I., Strzezik, J., (2014). Application of reflectance parameters in the estimation of the structural order of coals and carbonaceous materials. Precision and bias of measurements derived from the ICCP structural working group. - International Journal of Coal Geology, 131, 147-161.

Schulmann, K., Oliot, E., Košuličová, M., Montigny, R., Štípská, P. (2014). Variscan thermal overprints exemplified by U-Th-Pb monazite and K-Ar muscovite and biotite dating at the eastern margin of the Bohemian Massif (East Sudetes, Czech Republic). - Journal of Geosciences, 59, (4), 389-413.

Sivek, M., Dopita, M., Krůl, M., Čáslavský, M., Jirásek, J. (2003). Atlas of Chemical-Technological Properties of Coals in the Czech Part of the Upper Silesian Basin. - VŠB-TU, Ostrava, 31 p.

Środoń, J., Clauer, N., Banaś, M., Wójtowicz, A. (2006). K-Ar evidence for a Mesozoic thermal event superimposed on burial diagenesis of the Upper Silesia Coal Basin. - Clay Minerals, 41, 669-690. https://doi.org/10.1180/0009855064120212

Sweeney, J. J., Burnham, A. K. (1990). Evaluation of a simple model of vitrinite reflectance based on chemical kinetics. - American Association of Petroleum Geologists Bulletin, 74, 1559-1570. 